\title{
Originals
}

\section{The Risk of Diabetic Control: A Comparison of Hospital Versus General Practice Supervision}

\author{
A. Basdevant ${ }^{1}$, D. Costagliola ${ }^{3}$ J.L. Lanöe ${ }^{2}$, C. Goldgewicht ${ }^{1}$, A. Triomphe ${ }^{2}$, F. Metz ${ }^{1}$, H. Denys ${ }^{1}$, E. Eschwege ${ }^{3}$, \\ M. Fardeau ${ }^{2}$ and G. Tchobroutsky ${ }^{1}$ \\ 'Diabetes Unit, Hotel-Dieu Hospital, Université Pierre et Marie Curie, ${ }^{2}$ Laboratoire d'Economie Sociale, Université Paris I, \\ French Social Welfare Administration and ${ }^{3}$ Statistical Research Unit (INSERM), Paris, France
}

\begin{abstract}
Summary. Two groups of insulin-treated outpatients (one followed up at the Hotel-Dieu Hospital and the second mainly supervised by general practitioners) were chosen at random in 1978 . The two populations were comparable in age, age at diagnosis, sex, level of education, overall activity and socio-professional and economic status. Outpatients followed up in the diabetic unit had better blood glucose control, with about the same number of hypoglycaemic reactions as patients followed up in general practice. This better control was associated with more social activity and less visits to the physician, despite the fact that patients attending the hospital spent more money on their diet and had more daily insulin injections. All these differences remain significant after adjustment for the duration of diabetes. It may be inferred that attempts to improve control in insulin-treated patients are associated with a more active life and with no increase in the frequency of hypoglycaemic reactions.
\end{abstract}

Key words: Diabetes mellitus, insulin-treated diabetics, multiple injections, control of diabetes, hypoglycaemia.

Following several controversial publications on the control of diabetes [1, 2], Ingelfinger [3] stressed that 'almost nothing is known of the risks, in particular hypoglycaemia, of attempting to implement control'.

We have studied two groups of insulin-treated diabetic patients, treated either in a diabetic unit or by general practitioners, in order to evaluate the consequences of diabetes and its treatment. Attempts were made to analyse several parameters including the frequency of hypoglycaemic reactions, the quality of social and professional life, exercise and general wellbeing.

\section{Subjects and Methods}

This study deals with two groups of diabetic outpatients selected at random from two populations of diabetic patients who came at least once in 1974 to the clinic at Hotel-Dieu Hospital or who were registered as diabetic in the same geographical area at the Caisse d'Assurance Maladie. This department belongs to the French Social Welfare Administration where, since 1974, a file on all registered diabetic patients has been kept. All patients were clinically examined and interviewed in 1978 at Hotel-Dieu or the Caisse d'Assurance Maladie and data were recorded for the last 12-month period.

All the patients were seen by doctors and economists. Questionnaires were completed, collecting information on social and professional life, exercise and hobbies.

The nine socio-professional categories established by Institut National de la Statistique et des Etudes Economiques (INSEE) [4] divide French households into nine groups based upon social and professional criteria. On account of the small number of subjects in our study, we chose to combine the nine socio-professional categories into three groups (that is low, middle and high income) [5]. Those subjects who were retired or unemployed were allocated to one of the three groups according to their past job and/or their educational level. An index of social life and an assesment of professional life was made using the questionnaire shown in Table 1.

A medical history was taken and a full examination was carried out on every subject. This included measurement of height, weight and arterial blood pressure. Particular attention was paid to the presence or absence of diabetic complications. The control of diabetes was judged by mean fasting and post-prandial blood glucose levels and $24 \mathrm{~h}$ glycosuria. Each patient underwent at least four evaluations during the 12 months. Severe hypoglycaemia was defined as coma, the need for glucagon injection, emergency hospitalisation or the need for assistance. These data were obtained both from medical records and by direct questioning.

We used the $\chi^{2}$ statistics, the comparison of means and classical adjustment techniques: the chi-square of Cochran [6] for fourfold tables for qualitative data, and the two way analysis of variance with unequal sample size for the quantitative ones.

This study deals only with insulin-treated patients. It can be seen from Table 2 that $31 \%$ of the patients selected from the Caisse d'Assurance Maladie and 43\% from the Hotel-Dieu were insulintreated $(p<0.01)$. Some patients selected for the study failed to participate. The percentage of insulin-treated patients who did not attend was significantly higher among the Hotel-Dieu patients.

At Hotel-Dicu the insulin-treated patients who failed to partici- 
Table 1. Social and professional life assessment

Do you dine out with the family?
never
sometimes each year
sometimes each month
sometimes each week

Do you dine at home with the family? ${ }^{\mathrm{a}}$

never

sometimes each year

sometimes each month

sometimes each week

Do you dine out with friends? ${ }^{a}$

never

sometimes each year

sometimes each month

sometimes each week

Do you dine at home with friends? ${ }^{a}$

never

sometimes each year

sometimes each month

sometimes each week

Do you go to restaurants? ${ }^{\text {a }}$

never

sometimes each year

sometimes each month

sometimes each week

Do you go to shows?

never

sometimes each month

sometimes each week

Do you practise sports?

never

sometimes each year

sometimes each month

sometimes each week

Do you practise gardening?

never

sometimes each month

sometimes each week

Do you practise other leisure activities?

never

sometimes each year

sometimes each month

How many days have you been unemployed (due to illness or dismissal) in the previous year?

Does diabetes affect your job?

no

a little

more or less

a lot

Rate your working conditions

poor

fair

good

Do you have a fear of difficulties in obtaining a new job?

Yes

No

a An index of social life was obtained by addition of the nine scores, thus ranging from 9 (very active) to 36 (very inactive)
Table 2. Description of the two patient groups

\begin{tabular}{|c|c|c|c|c|}
\hline & $\begin{array}{l}\text { French So- } \\
\text { cial Welfare } \\
\text { Administra- } \\
\text { tion }\end{array}$ & $\begin{array}{l}\text { University } \\
\text { Hospital } \\
\text { (Hôtel-Di- } \\
\text { eu Paris) }\end{array}$ & $p$ & $p^{\mathrm{a}}$ \\
\hline $\begin{array}{l}\text { No. of selected dia- } \\
\text { betics }\end{array}$ & 227 & 280 & & \\
\hline $\begin{array}{l}\text { No. of insulin-treated } \\
\text { diabetics }\end{array}$ & 71 & 121 & & \\
\hline $\begin{array}{l}\text { No. of insulin-treated } \\
\text { patients examined } \\
\text { (percentage of select- } \\
\text { ed) }\end{array}$ & $64(90)$ & $83(69)$ & $<0.01$ & \\
\hline $\begin{array}{l}\text { Duration of diabetes } \\
\text { (years) }^{b}\end{array}$ & $16 \pm 8$ & $13 \pm 7$ & $<0.01$ & \\
\hline Percentage men & 52 & 48 & NS & NS \\
\hline Age in 1978 (years) $^{b}$ & $46 \pm 13$ & $45 \pm 13$ & NS & NS \\
\hline $\begin{array}{l}\text { Age at diagnosis } \\
\text { (years) }^{b}\end{array}$ & $30 \pm 13$ & $32 \pm 13$ & NS & NS \\
\hline Body mass index ${ }^{b, c}$ & $38 \pm 6$ & $36 \pm 5$ & $<0.05$ & NS \\
\hline $\begin{array}{l}\text { Percentage of } \\
\text { patients who were } \\
\text { hypertensive }\end{array}$ & 16 & 19 & NS & NS \\
\hline
\end{tabular}

a Value when the duration of diabetes was held constant

b Results expressed as mean \pm SD

c Body mass index [7] calculated by the formula $100\left(\log \frac{\text { weight }(\mathrm{kg})}{\text { height }^{2}(\mathrm{~m})}-1\right)$

Table 3. Modes of follow up since the diagnosis of diabetes

\begin{tabular}{|c|c|c|c|c|}
\hline & $\begin{array}{l}\text { French } \\
\text { Social } \\
\text { Welfare } \\
\text { Adminis- } \\
\text { tration } \\
(n=64)^{a}\end{array}$ & $\begin{array}{l}\text { University } \\
\text { Hospital } \\
\text { (Hôtel- } \\
\text { Dieu Paris) } \\
(n=83)^{\mathrm{a}}\end{array}$ & $p$ & $p^{\mathrm{b}}$ \\
\hline \multicolumn{5}{|l|}{ Diagnosis made by: } \\
\hline $\begin{array}{l}\text { General practi- } \\
\text { tioners }\end{array}$ & 56 & 71 & \multirow{3}{*}{$<0.05$} & \multirow{3}{*}{ NS } \\
\hline $\begin{array}{l}\text { At hospital or } \\
\text { in welfare cen- } \\
\text { tre }\end{array}$ & 33 & 16 & & \\
\hline $\begin{array}{l}\text { By physician } \\
\text { practising at } \\
\text { place of work }\end{array}$ & 11 & 13 & & \\
\hline \multicolumn{5}{|c|}{ Mode of follow-up (since the diagnosis) } \\
\hline $\begin{array}{l}\text { General practi- } \\
\text { tioner only }\end{array}$ & 16 & $0)$ & \multirow{3}{*}{$<0.001$} & \multirow{3}{*}{$<0.01$} \\
\hline Hospital only & 14 & 16 & & \\
\hline Both & 70 & 841 & & \\
\hline \multicolumn{5}{|c|}{ Mode of follow-up in 1978} \\
\hline tioner & 42 & 4 & \multirow[t]{2}{*}{$<0.001$} & \multirow[t]{2}{*}{$<0.001$} \\
\hline Hospital & 58 & 96 & & \\
\hline
\end{tabular}

${ }^{a}$ Expressed as percentage of total patients

$b$ Value when the duration of diabetes was held constant 
pate were not different from those who attended for examination in respect of age, sex, socio-professional status or body mass index [7]. However, the duration of diabetes was longer among those who failed to participate than in those who attended $(17 \pm 10$ versus 13 \pm 7 years, $p<0.05$ ). The seven patients from the Caisse d'Assurance Maladie who failed to participate were also not different from the patients who attended for asessment.

Tables 2, 3 and 4 present the two patient groups in terms of their age, socio-economic status and the other factors described. These did not differ in sex, age at examination, age at diagnosis, family size, level of education, and socio-professional status. The HotelDieu patients were more often cared for in the clinic only (or in the clinic and by their private physician) than the patients of Caisse d'Assurance Maladie, who had a higher percentage of care by a private physician alone ( $42 \%$ of patients of this last group were followed by a private physician versus only $4 \%$ in the other group).

Since the patients who took part from Hotel-Dieu had a significantly shorter duration of diabetes than those who failed to attend for study, we adjusted all comparisons between the two groups for the duration of the disease. We divided the duration of diabetes into four categories, and for each qualitative variable studied we combined the results obtained in each category following the method described by Cochran [6]; for the quantitative variables we took into account the effect of the duration of the disease by using a two way analysis of variance with unequal sample size. After adjustment for the duration of diabetes, all the significant differences between the two groups remained significant except for the body mass index.

\section{Results}

Outpatients attending the Hôtel-Dieu Hospital had lower blood glucose levels when fasting and after meals than the patients from the other group who were usually treated by general practitioners (Table 5 ). The majority $(91 \%)$ of Hotel-Dieu patients gave themselves two or three injections per day, while $42 \%$ of patients from Caisse d'Assurance Maladie gave themselves one injection per day. This better control

Table 4. Socio-economic data in the two patient groups

\begin{tabular}{|c|c|c|c|c|}
\hline & $\begin{array}{l}\text { French So- } \\
\text { cial Welfare } \\
\text { Administra- } \\
\text { tion } \\
(n=64)^{a}\end{array}$ & $\begin{array}{l}\text { University } \\
\text { Hospital } \\
\text { (Hôtel-Di- } \\
\text { eu Paris) } \\
(n=83)^{\mathrm{a}}\end{array}$ & $p$ & $p^{\mathrm{b}}$ \\
\hline \multicolumn{5}{|c|}{ No. of people living at home: } \\
\hline 1 & 14 & 7 & \multirow{4}{*}{ NS } & \multirow{4}{*}{ NS } \\
\hline 2 & 39 & 33 & & \\
\hline 3 & 17 & 33 & & \\
\hline 4 & 30 & 27 & & \\
\hline $\begin{array}{l}\text { Educational level: } \\
\text { elementary }\end{array}$ & 45 & $37)$ & \multirow{3}{*}{ NS } & \multirow{3}{*}{ NS } \\
\hline secondary & 35 & 27 & & \\
\hline higher & 20 & 36 & & \\
\hline $\begin{array}{l}\text { Percentage of activ } \\
\text { people }\end{array}$ & 72 & 65 & NS & NS \\
\hline \multicolumn{5}{|l|}{ Income level ${ }^{\mathrm{c}}$ : } \\
\hline low income & 28 & $15)$ & \multirow{3}{*}{ NS } & \multirow{3}{*}{ NS } \\
\hline middle income & 59 & 75 & & \\
\hline high income & 13 & 11 & & \\
\hline
\end{tabular}

Table 5. Treatment, control and hypoglycaemic reactions in the two patient groups

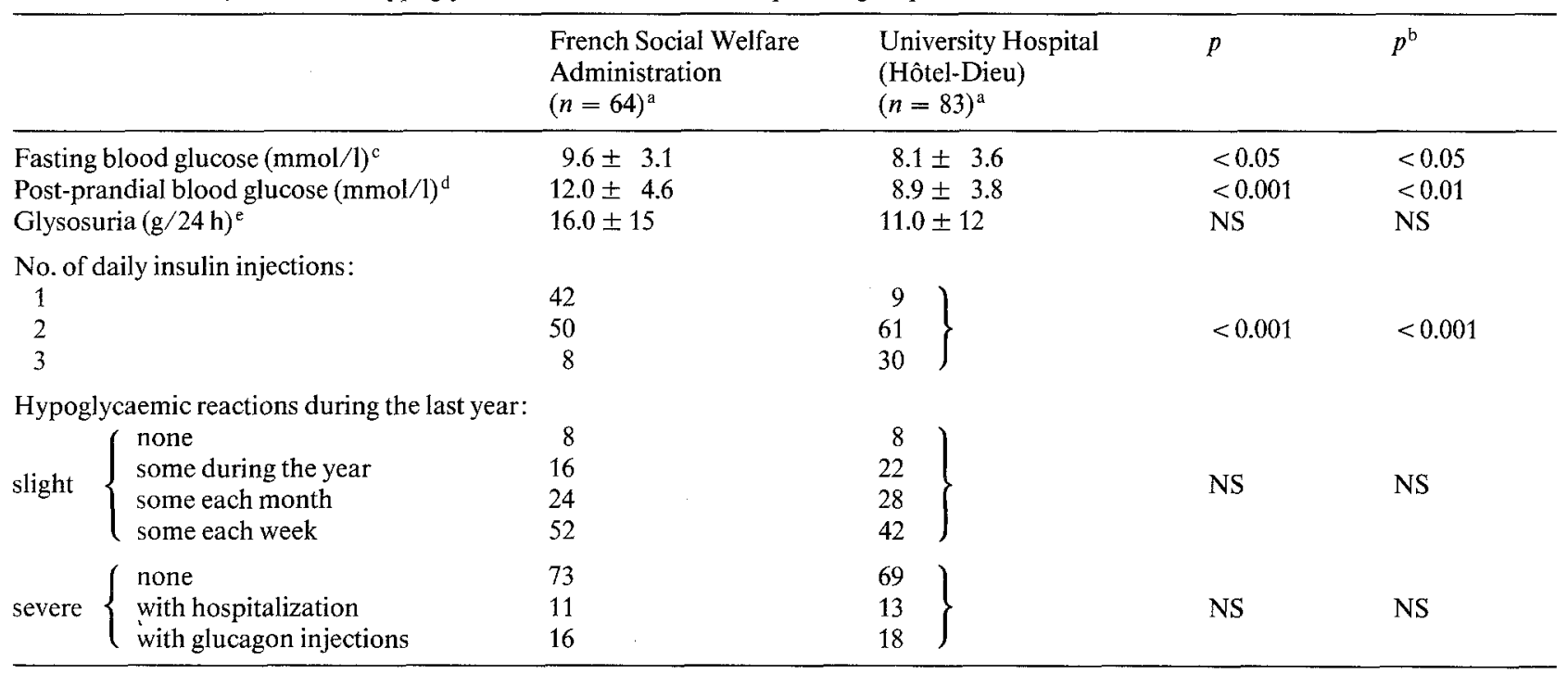

Results expressed as mean \pm SD

a Expressed as percentage of total patients

b Value when the duration of diabetes was held constant

c Missing information for 12 patients in the first group, and 8 in the second

d Missing information for 35 patients in the first group and 12 in the second

e Missing information for 34 patients in the first group and 24 in the second 
Table 6. Social and professional life data in the two patient groups

\begin{tabular}{|c|c|c|c|c|}
\hline & $\begin{array}{l}\text { French Social Welfare } \\
\text { Administration } \\
(n=64)^{a}\end{array}$ & $\begin{array}{l}\text { University Hospital } \\
\text { (Hôtel-Dieu) } \\
(n=83)^{\mathrm{a}}\end{array}$ & $p$ & $p^{\mathrm{b}}$ \\
\hline Index of social life ${ }^{c}$ & $28.56 \pm 5.02$ & $25.70 \pm 5.41$ & $<0.01$ & $<0.01$ \\
\hline $\begin{array}{l}\text { Dining out with friends: } \\
\text { never } \\
\text { sometimes/year } \\
\text { sometimes/month } \\
\text { sometimes/week }\end{array}$ & $\begin{array}{r}31 \\
50 \\
8 \\
11\end{array}$ & $\left.\begin{array}{l}31 \\
31 \\
21 \\
17\end{array}\right\}$ & $<0.05$ & NS \\
\hline $\begin{array}{l}\text { Dining at home with friends: } \\
\text { never } \\
\text { sometimes/year } \\
\text { sometimes/month } \\
\text { sometimes/week }\end{array}$ & $\begin{array}{r}40 \\
42 \\
10 \\
8\end{array}$ & $\left.\begin{array}{l}29 \\
32 \\
26 \\
13\end{array}\right\}$ & $<0.05$ & NS \\
\hline $\begin{array}{l}\text { Do you practise gardening or ot } \\
\text { activities? } \\
\text { never } \\
\text { sometimes/year } \\
\text { sometimes/month } \\
\text { sometimes/week }\end{array}$ & $\begin{array}{r}50 \\
19 \\
8 \\
23\end{array}$ & $\left.\begin{array}{r}37 \\
6 \\
16 \\
41\end{array}\right\}$ & $<0.05$ & $<0.05$ \\
\hline $\begin{array}{l}\text { Do you think you could have } \\
\text { difficulty or have you had } \\
\text { difficulty in getting a new job? } \\
\text { percentage of 'yes' }\end{array}$ & 44 & 69 & $<0.01$ & $<0.05$ \\
\hline
\end{tabular}

a Expressed as percentage of total patients

b Value when the duration of diabetes was held constant

${ }^{c}$ Results expressed as mean $\pm \mathrm{SD}$. This index ranging from nine (very active) to 36 (very inactive) was compiled based on nine questions about social and leisure activities

Table 7. Way of life with diabetes in the two patient groups

\begin{tabular}{|c|c|c|c|c|}
\hline & $\begin{array}{l}\text { French Social Welfare } \\
\text { Administration } \\
(n=64)\end{array}$ & $\begin{array}{l}\text { University Hospital } \\
\text { (Hôtel Dieu) } \\
(n=83)\end{array}$ & $p$ & $p^{\mathrm{a}}$ \\
\hline No. of medical consultations/year & $7.9 \pm 5.5$ & $3.7 \pm 3.0$ & $<0.001$ & $<0.001$ \\
\hline $\begin{array}{l}\text { Percentage of people hospitalized at least } \\
\text { once } \\
\text { Does the special diet entail some additional } \\
\text { expenses (patient's view) }\end{array}$ & 86 & 94 & NS & NS \\
\hline percentage of 'yes' & 48 & 67 & $<0.05$ & $<0.01$ \\
\hline $\begin{array}{l}\text { Do you know about glucagon? } \\
\text { percentage of 'yes' }\end{array}$ & 81 & 99 & $<0.001$ & $<0.001$ \\
\hline
\end{tabular}

Results expressed as mean $\pm \mathrm{SD}$

a Value when the duration of diabetes was held constant

was not associated with a higher incidence of hypoglycaemic reactions (either slight or severe).

It is of interest that $31 \%$ of patients from HotelDieu and $27 \%$ of patients from Caisse d'Assurance Maladie experienced at least one severe hypoglycaemic reaction during the last year.

Table 6 shows the significant results from the questions concerning social and professional life. The better control among the Hotel-Dieu patients was as- sociated with a more active social life, including more social eating habits and more participation in leisure activities. The patients followed at Hotel-Dieu Hospital were not different from those of the Caisse d'Assurance Maladie with regard to the number of days of unemployment due to illness or dismissal. There was no difference in relation to the ease of gaining new employment, although the feeling that diabetes was a possible handicap was greater among Hotel-Dieu pa- 
tients than among those from Caisse d'Assurance Maladie.

The feeling of well-being was greater in HotelDieu patients than among those from the Caisse d'Assurance Maladie, and this despite the fact that Hotel-Dieu patients spent more money on their diet (Table 7) and had more insulin injections per day (30\% of Hôtel-Dieu take three injections versus $8 \%$ of Caisse d'Assurance Maladie patients). Finally, patients from Hotel-Dieu were more often hospitalised, but had visited their physician less frequently during the last year, and knew more about their diabetes (as reflected for instance by knowledge of glucagon) than the diabetics of the other group. At Hôtel-Dieu diabetic patients are usually admitted once for evaluation and education.

It is of interest to note that, when controlling for the educational level of the patient, none of the results were significantly altered.

\section{Discussion}

We have compared two populations of insulin-treated diabetic patients, one of which was followed up in a diabetic unit and the other by general practitioners. Both populations were subject to a large risk of hypoglycaemic reactions since $27 \%$ in Caisse d'Assurance Maladie and 31\% at Hotel-Dieu had at least one severe hypoglycaemic episode during the year before the survey. However, the two groups were not different in this regard despite the fact that the group of patients in Hotel-Dieu achieved a better blood glucose control than the other group. The group of patients treated at Hotel-Dieu had no disadvantages compared with the other group: all comparisons between groups showed either no difference or else the difference was always in favour of hospital management. The group managed by the diabetic unit spent more time on social activities and had a greater feeling of well-being. These results may indicate that the quest for better control, including more frequent insulin injections, does not increase the risk of the treatment. We have defined significant hypoglycaemia using several criteria and have shown that about one out of four patients in both groups experienced at least one severe hypoglycaemic reaction per year. We were unable to find figures in the literature that would allow any comparisons with our findings. Data are given for cause of death in patients from the Joslin Clinic, where there was emphasis on obtaining 'tight control'; (in reviews by Marble [8], and Paz-Guevara et al. [9]). Deaths due to hypoglycaemia were rare $(0.23 \%)$ [8].
Among 3,000 children followed by Lestradet et al. [10] for 30 years, seven died of hypoglycaemia. However, there is virtually no information concerning reversible or irreversible damage to the central nervous system induced by hypoglycaemia. In the Joslin Clinic report [11], two cases were described but overall figures were not given. In another study conducted at Hotel-Dieu Hospital the authors observed that about $25 \%-30 \%$ of insulin-treated patients experienced at least one severe hypoglycaemic reaction per year [12]. Finally, as emphasized by Ingelfinger [3], reliable data indicating the incidence or prevalence of adverse effects induced by the quest for better control are very scarce.

One question remains. Are the insulin-treated patients who where followed up in Hotel-Dieu Hospital different from those who were followed up by general practitioners? For the studied variables (age, sex, level of education, socio-professional and economic status) the two populations of insulin-treated patients were not significantly different (at the 5\% level) except for a shorter duration of diabetes among those from Hotel-Dieu. Therefore this variable was taken into account for all the comparisons between the two groups. However, the treatments of the two groups were different since in the specialised unit (Hotel-Dieu) daily insulin injections were more frequent and education was more intensive. Furthermore, the groups of patients (as well as their physicians), probably differed in their attitude: those from Hotel-Dieu came at least once to a specialised clinic and were more often hospitalised for teaching and treatment modification. The patient followed up at Hotel-Dieu Hospital were perhaps looking for more information, more advice, and more rigid control. They were willing to try to achieve good control [13] even if the large majority of them had been referred to this hospital by their general practitioners and were ignorant of the aims of the specialised unit [14]. Psychological tests were not performed on the subjects, but it is likely that the psychological profile of a subject who chooses to be followed up in a specialised unit (or who is referred to a specialised unit) is different from the profile of a patient who is followed up in general practice. Our study is not a randomized study but an observational one and thus we cannot be sure that there is no bias of recruitment. Another further question is whether trying to improve the control of blood glucose and to increase the knowledge about diabetes in a different group of diabetics will lead to the same results, i.e. no increased risks but increased benefits.

In insulin-treated diabetic patients who nowadays hope for a long life expectancy without physiological or social handicaps, an improvement of control will probably be beneficial in lowering the occurrence and 
severity of microangiopathy [15], although the relationship between blood glucose control and the evolution of microvascular disease in diabetes is still under discussion [1, 2]. The results of this study may indicate that the desire for better control does not increase the social restrictions placed on the diabetic or the risk of more frequent hypoglycaemic reactions. Furthermore, several studies of self-monitoring of blood glucose have shown that those techniques which improve control by increasing knowledge, particularly in well motivated patients, will also improve their well-being $[16,17]$.

Finally our results also showed that the better controlled patients spent less time visiting physicians. This can certainly be added to the list of the benefits, not only for the patient but also for the medical and social welfare administration.

Acknowledgements. This study was supported by grants from INSERM ATP N56. The authors are grateful to G.Vuillemin, E. Barraud, C.Mondou, M.C.Bel, J.Deruelle, C.Vuillemin, N. Thibult for their participation in the study.

\section{References}

1. Cahill GF, Etzwiler DD, Freinkel N (1976) Control and diabetes. N Engl J Med 294: 1004-1005

2. Siperstein MD, Foster DW, Knowles HC Jr, Levine R, Madison LL, Roth J (1977) Control of blood glucose and diabetic vascular disease. $\mathrm{N}$ Engl J Med 296: 1060-1063

3. Ingelfinger FJ (1977) Debates on diabetes. N Engl J Med 296: $1228-1230$

4. INSEE (1980) Code des catégories socio-professionnelles, 7ème edn. INSEE, Paris

5. INSEE (1978) Données sociales. La documentation française. INSEE, Paris, $p 48$

6. Cochran WG (1968) The effectiveness of adjustment by subclassification in removing bias in observational studies. Biometrics 24: $295-313$
7. Schwartz D, Lellouch J, Anguerra FG, Beaumont JL, Lenegre J (1966) Tobacco and other factors in the aetiology of ischemic heart disease in men. Results of a retrospective survey. J Chronic Dis 19:35-56

8. Marble A (1971) Hypoglycaemia due to insulin. In: Marble A, White P, Bradley RF, Krall LP(eds) Treatment of diabetes mellitus, 11th edn. Lea \& Febiger, Philadelphia, pp 297-301

9. Paz-Guevara AT, Hsu TH, White P (1975) Juvenile diabetes mellitus after forty years. Diabetes $24: 559-565$

10. Lestradet H, Papoz L, Hellouin de Menibus Cl, Levavasseur F, Besse J, Billaud L, Battisteli F, Tric Ph, Lestradet F(1981) Longterm study of mortality and vascular complications in juvenileonset (Type 1) diabetes. Diabetes 30:175-179

11. Marble A (1959) Hypoglycaemia due to insulin. In: Joslin EP, Rooth HF, White EP, Marble A (eds) The treatment of diabetes mellitus, 10th edn. Lea \& Febiger, Philadelphia, pp 319-320

12. Goldgewicht C, Slama G, Papoz L, Gin H, Soria J, Desplanque N, Tchobroutsky G (1981) Les hypoglycémies vécues par les diabétiques insulino-traités. In: Journées Annuelles de Diabetologie Hotel-Dieu, Flammarion, Paris, pp 247-256

13. Malins J (1968) Management of diabetes. In: Malins J (ed) Clinical diabetes mellitus. Eyre \& Spottiswood, London, pp $447-448$

14. Denys H, Traynard PY, Manuellan PE (1981) Les aspects psycho-sociaux dans le traitement des diabétiques insulino-dépendants. Le rôle de l'équipe soignante. In: Journées Annuelles de Diabetologie Hotel-Dieu, Flammarion, Paris, pp 237-246

15. Tchobroutsky G (1978) Relation of diabetic control to development of microvascular complications. Diabetologia 15: 143-152

16. Peterson CM, Rorhan SE, Jones RL (1980) Self-management: an approach to patients with insulin-dependent diabetes mellitus. Diabetes Care 3:82-87

17. Sönksen PH, Judd S, Lowy C (1980) Home monitoring of blood glucose: new approach to management of insulin-dependent diabetic patients in Great Britain. Diabetes Care 3:100-107

Received: 14 May 1981

and in revised form: 15 December 1981

Dr. G.Tchobroutsky

Hotel-Dieu

Place du Parvis Notre-Dame

F-75181 Paris Cédex 04, France 